\title{
PRELIMINARY STUDY ON AGE, GROWTH AND REPRODUCTION OF MUSTELUS MUSTELUS (ELASMOBRANCHII: CARCHARHINIFORMES: TRIAKIDAE) INHABITING THE GULF OF ISKENDERUN, NORTH-EASTERN MEDITERRANEAN SEA
}

\author{
Ebru Ifakat OZCAN ${ }^{1,2 *}$ and Nuri BAŞUSTA ${ }^{2}$ \\ ${ }^{1}$ Faculty of Fisheries, Munzur University, Tunceli, Turkey \\ ${ }^{2}$ Faculty of Fisheries, Firat University, Elazlğ, Turkey
}

Ozcan E.I., Başusta N. 2018. Preliminary study on age, growth and reproduction of Mustelus mustelus (Elasmobranchii: Carcharhiniformes: Triakidae) inhabiting the Gulf of Iskenderun, north-eastern Mediterranean Sea. Acta Ichthyol. Piscat. 48 (1): 27-36.

\begin{abstract}
Background. Shark populations within the eastern Mediterranean are declining due to overfishing. Unfortunately, our knowledge on the biology of sharks and specifically dogfishes within eastern Mediterranean is extremely limited due to the lack of landings. Mustelus mustelus (Linnaeus, 1758) is one of such deficiently known cartilaginous fishes and the relevant information on its age and growth in the eastern Mediterranean is missing. The understanding of growth and reproductive behaviour is important for management and conservation of this species. The presently reported study was intended to determine age, growth, and some reproductive parameters of Mustelus mustelus collected in the Gulf of Iskenderun, the north-eastern Mediterranean Sea.

Materials and methods. In this study, a total of 155 Mustelus mustelus were caught in the north-eastern Mediterranean Sea between March 2012 and October 2015. Fish age was determined based on band counts of sectioned vertebrae. The periodicity of band pair formation was examined using the marginal increment analysis. Growth parameters for all specimens were then determined by fitting the observed and the length-at-age data using the von Bertalanffy Growth Equation. The size and age at which $50 \%$ of both sexes reached maturity was estimated by a logistic model for maximum likelihood process and the gonadosomatic index was determined.

Results. The total length and weight of the specimens examined ranged from 44.3 to $162.6 \mathrm{~cm}$ and from 241.3 to $12060 \mathrm{~g}$, respectively. The presently reported study provides new maximum lengths $(162.6 \mathrm{~cm})$ for M. mustelus from the north-eastern Mediterranean. The fish studied represented age groups from 0 through 25 . The observed sex ratio was $1 \div 1.04$ (females $\div$ males). Von Bertalanffy growth parameters were estimated to be $L_{\infty}=195.13 \mathrm{~cm}$, $W_{\infty}=20060 \mathrm{~g}, K=0.06$, and $t_{0}=-4.27$ for all specimens. Length-weight relation was found to be $W=0.0027 L^{3.0054}$ $\left(R^{2}=0.98\right)$ and $95 \%$ confidence intervals of $b=2.936-3.075, t$-test $P<0.05$. All studied specimens of $M$. mustelus represented isometric growth $(b=3)$. Condition factor ranged from 0.148 to 2.87 for females and from 0.103 to 1.024 for males. The length at 50\% maturity and the age at $50 \%$ maturity were $109 \mathrm{~cm}$ and 8 in females and $92 \mathrm{~cm}$ and 7 in males, respectively. It was observed that mean GSI values were low in September and July, reaching a maximum in January to February.

Conclusion. The results of this study could give useful insight for management plans and conservation of M. mustelus in the Mediterranean coast of Turkey.
\end{abstract}

Keywords: smoothhound, Mustelus mustelus, length-weight relations, gonadosomatic index, condition factor

\section{INTRODUCTION}

Smooth-hound sharks belong to the genus Mustelus (family Triakidae), which includes 34 valid species occurring in all major oceans. Five of those species can be found in the Mediterranean. Mustelus mustelus (Linnaeus, 1758 ) is a demersal species inhabiting sandy or muddy bottom down to the depths of $150 \mathrm{~m}$ (Golani et al. 2006). This species is caught in small numbers by bottom trawl and they have minor commercial value in Turkey (Başusta and Erdem 2000). The most important prey-groups for the species in the north-eastern Mediterranean are crustaceans and fishes (Özcan and Başusta 2016).

Sharks and specifically dogfishes have become an important commodity as a fishery resource in today's world, where alternative seafood supplies have gained importance. In spite of this, there is almost no detailed biological information about this species. It is known that dogfishes have low growth rate, reach sexual maturity at later age, and their fecundity is rather low (Cailliet et al. 1993). Mustelus mustelus is a widespread species,

“ Correspondence: Dr. Ebru İfakat Özcan, Munzur Üniversitesi, Su Ürünleri Fakültesi, Tunceli, Turkey, phone: +90 5317409095, e-mail: (EIO) ebruozer@munzur.edu.tr, (NB)nbasusta@hotmail.com. 
although not abundant. The species may be threatened with extinction in the future (Serena et al. 2009).

Length-weight relations (LWRs) are of high importance to compare life histories of fishes between different areas (Hossain et al. 2013). The results will be useful for sustainable management and protection of the limited stocks in the north-eastern Mediterranean Sea.

The aim of this study was to determine, for the first time, age, growth, length-weight relations, and reproductive biology of $M$. mustelus in the north-eastern Mediterranean Sea.

\section{MATERIALS AND METHODS}

The samples were obtained monthly by gill nets and long-lines between March 2012 and October 2015 in the north-eastern Mediterranean Sea including the Gulf of Iskenderun, Turkey (Fig. 1). Following transportation of the samples to the laboratory, the identification of species was made according to Golani et al. (2006). For each fish total length (TL) and weight were determined to the nearest $0.1 \mathrm{~cm}$ or $0.1 \mathrm{~g}$, respectively. Presence or absence of claspers aided sex identification.

A total of 12 vertebral centra were dissected from above the abdominal cavity of 155 Mustelus mustelus, stored frozen (for methodology see Türkmen et al. 2005). Vertebrae were then separated from each other and immersed in warm distilled water (Martin and Cailliet 1988, Cailliet and Goldman 2004, Cailliet et al. 2006, Duman and Başusta 2013). Large vertebrae, exceeding $5 \mathrm{~mm}$ in diameter were divided using a gem saw (Ray Tech) with two diamond blades separated by a $0.6 \mathrm{~mm}$ spacer (Başusta and Sulikowski 2012). Smaller vertebrae were sanded with a Dremel tool to replicate a sagittal cut (Sulikowski et al. 2005, Başusta et al. 2008). Reading of the vertebral sections was done using a light-reflecting microscope. One growth band was defined as an opaque and translucent band pair that traversed the intermedialia and clearly extended into the corpus calcareum (Fig. 2).

The index of the mean percentage error* (IMPE) was calculated to assess the precision of the age determinations between 2 independent readers. The equation is expressed as follows:

$$
\mathrm{IMPE}=\frac{1}{n} \sum_{j=1}^{N}\left(\frac{1}{N} \sum_{i=1}^{R} \frac{\left|X_{i j}-X_{j}\right|}{X_{j}}\right) \times 100 \%
$$

where $n$ is the number of fish aged, $N=$ number of times each fish was aged, $X_{i j}$ is the $i$ th age determination of the $j$ th fish, $X_{j}$ is the mean age calculated for the $j$ th fish (Beamish and Fournier 1981). Age determination bias between readers was assessed using an age-bias plot (Campana 2001, Cailliet and Goldman 2004).

The periodicity of band pair formation was examined using the marginal increment ratio (MIR) (Sulikowski et al. 2003). The MIR was calculated as the ratio of the margin between the last and penultimate opaque bands as measured with an optical micrometre. The marginal increment ratio (MIR) was calculated by the following equation of Natanson et al. (1995)

$$
\mathrm{MIR}=\left(\mathrm{VR}-\mathrm{VR}_{n}\right) \times\left(\mathrm{VR}_{n}-\mathrm{VR}_{n-1}\right)^{-1}
$$

where $\mathrm{VR}$ is the vertebral radius, and $\mathrm{VR}_{n}$ and $\mathrm{VR}_{n-1}$ are the last and penultimate opaque bands, respectively. A sub-sample of 48 vertebrae was selected comprising both juvenile and adult specimens collected nearly every month except August. Kruskal-Wallis one-way analysis of variance on ranks was used to test for differences in marginal increment by month (Cailliet et al. 1990, Sulikowski et al. 2003).

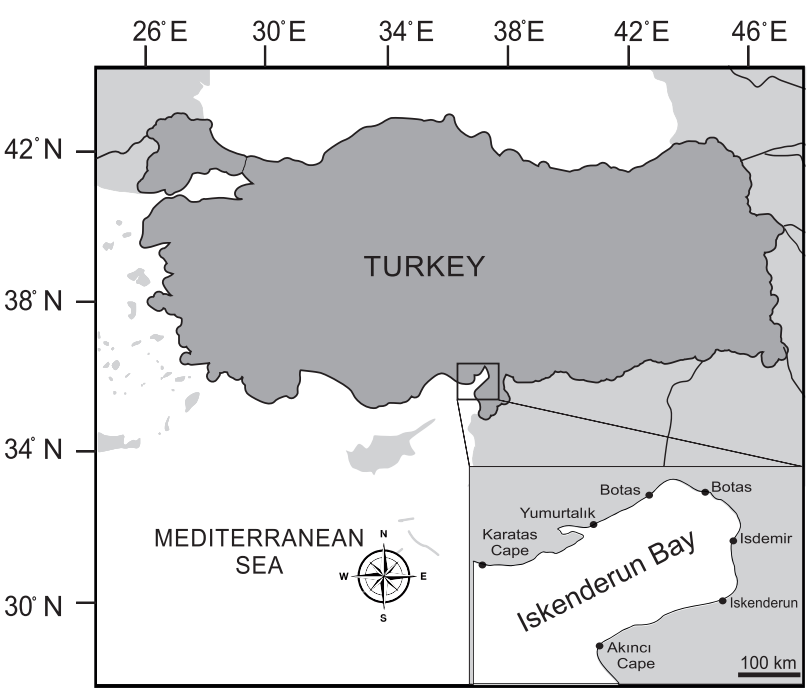

Fig. 1. The sampling area of Mustelus mustelus in the Gulf of Iskenderun, north-eastern Mediterranean Sea

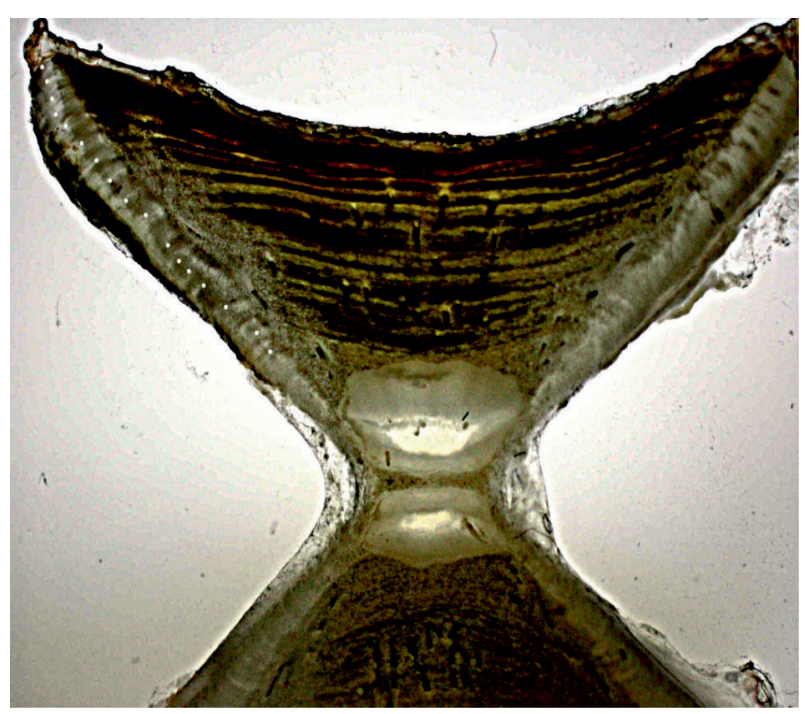

Fig. 2. Longitudinal cross-section of vertebral centrum of Mustelus mustelus (150.2 cm TL, estimated age 17 years) from the Gulf of Iskenderun, north-eastern Mediterranean Sea 
Length-based von Bertalanffy growth function This method utilizes binomial maturity stage (immature (VBGF) was determined with the formula (von Bertalanffy 1938)

$$
L_{t}=L_{\infty}\left[1-e^{-K(t-t 0)}\right]
$$

where $L_{t}$ is the expected total length at age $t$ years and $L_{\infty}$ is the asymptotic mean maximum total length, $K$ is the growth coefficient, and $t_{0}$ is the theoretical age at zero length.

The growth in weight was also described by the weight-based von Bertalanffy growth function

$$
W_{t}=W_{\infty}\left[1-e^{-K(t-t 0)}\right]^{b}
$$

where $W_{t}$ is total weight at time $t, W_{\infty}$ is the maximum theoretical weight of fish, and $b$ is power constant of length weight relations.

The relation between length and weight was calculated using the expression

$$
W=a L^{b}
$$

where $W$ is the total weight (TW) [g], $L$ is the total length (TL) $[\mathrm{cm}], a$ is the intercept of the regression, and $b$ the slope or regression coefficient. The $b$ values of both sexes for Mustelus mustelus were tested by using the Kolmogorov-Smirnov two-sample test, and the $b$ value variation from 3 was tested with the one sample $t$-test $(P<0.001)$. The degree of association between the variables was computed by the determination coefficient $R^{2}$ (King 1995).

Condition factor $K$ was determined by the formula

$$
K=\left(W \times \mathrm{TL}^{-b}\right) \times 100
$$

where $W$ is the total weight, TL is the total length, and $b$ is the coefficient of allometric relation (Bagenal and Tesch 1978).

The size and age at which $50 \%$ of both sexes reached maturity (TL50\% and A50\%, respectively) were estimated by a logistic model for maximum likelihood process (Ghorbel et al. 1996, Conrath and Musick 2002).

$=0$, mature $=1)$, so all specimens that were not capable of breeding (juveniles and maturing specimens) were grouped as immature.

The gonadosomatic index [\%] was determined using the formula

$$
\mathrm{GSI}=100 W_{\mathrm{g}} \cdot W_{\mathrm{t}}^{-1}
$$

where $W_{\mathrm{g}}$ is the gonad weight $[\mathrm{g}]$, and $W_{\mathrm{t}}$ is the total weight of fish [g] (Bagenal 1978).

\section{RESULTS}

A total of 155 individuals of Mustelus mustelus (76 females, 79 males) were collected during the study. The female $\div$ male ratio was found to be $1 \div 1.04$. Females ranged from 44.3 to $162.6 \mathrm{~cm}$ in total length (TL) and 241.3 to $12060 \mathrm{~g}$ in total weight $(W)$. Males ranged from 47.1 to $1490 \mathrm{~cm}$ in TL and 315.6 to $8776 \mathrm{~g}$ in $W$. The length differences between females and males were not statistically significant (Student's $t$-test, $P>0.05$ ). The total length-frequency distribution by sex is given in Fig. 3 . The strong linear relation between centrum diameter and TL indicates that the vertebrae provided a continuous record of body growth $\left(R^{2}=0.95\right)$ and therefore is a suitable structure for age interpretation in both male and female M. mustelus (Fig. 4).

The age of $M$. mustelus specimens was determined by vertebral band counts. The age ranged from 0 to 25 years. IMPE, which is the index of mean percentage error determined by two independent age readers, was found to be $3.03 \%$ for M. mustelus. This means that the confidence interval for the reliability of estimations was between $5 \%$ and $15 \%$, indicating that our ageing method represents a precise approach to the age determination of M. mustelus (Campana 2001, Girgin and Başusta 2016).

Marginal increment widths were significantly different between all months (Kruskal-Wallis, $P<0.001$ ), with increment growth beginning in January and peaking in July (Fig. 5). This peak was followed by a large decline in marginal increment growth, reaching minimum values in October. As such, these data suggest that a single opaque band is formed annually on the vertebral centra between

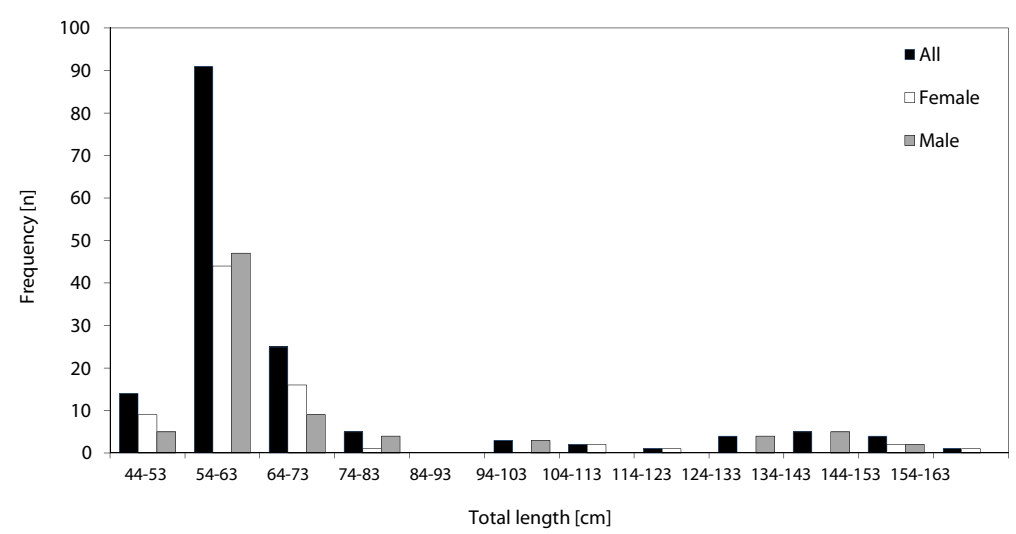

Fig. 3. Total length frequency analysis of Mustelus mustelus from the Gulf of Iskenderun, north-eastern Mediterranean Sea 
July and October. Age bias plot between readers for all age estimated is given in Fig. 6. Both readers estimated same age in 122 of 140 samples. The agreement between readers on all age assessment was $87 \%$. The agreement between readers was $89 \%$ within 1 year and $95 \%$ within 2 years. The difference between readers in the accuracy of age assessment was found insignificant when repeated annuli counts were compared (paired $t$-test, $P>0.05$ ).

In total, 75 individuals represented this age group (38 females and 37 males) and age 2 was the dominant age group among all (Table 1). Age, total length, and weight distribution of M. mustelus are given in Table 1 . Age-frequency distribution by sex is given in Fig. 7. The maximum length at age was determined as $162.6 \mathrm{~cm}$ at 25 years of age and $150.2 \mathrm{~cm}$ at 17 years of age (Fig. 2).

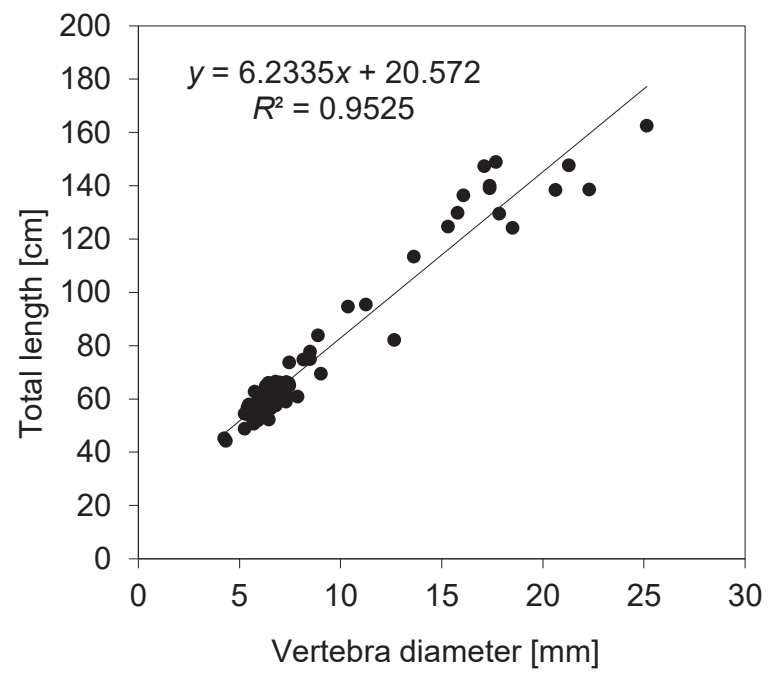

Fig. 4. The relation between the vertebral diameter and the total length of Mustelus mustelus from the Gulf of Iskenderun, north-eastern Mediterranean Sea

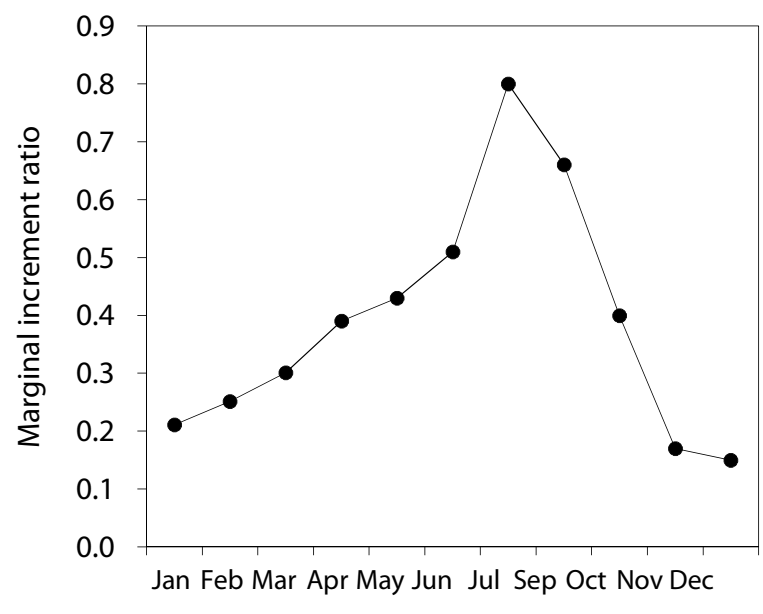

Months

Fig. 5. Monthly variation values of the marginal increment ratio of Mustelus mustelus from the Gulf of Iskenderun, north-eastern Mediterranean Sea
In this study, the estimated von Bertalanffy Growth Equation (VBGE) was $L_{t}=195.13\left[1-e^{-0.06(t+4.27)}\right]$ for both sexes combined by considering the length of fish based on the population of Mustelus mustelus in the north-eastern Mediterranean (Fig. 8). The maximum absolute growth of fish in 1-year age group was found to be $8.79 \mathrm{~cm}$; relative growth was calculated as $19.94 \%$. On the other hand, the minimum absolute growth in fish within the 25 years of age was found as $2.08 \mathrm{~cm}$; relative growth was calculated as $1.30 \%$.

The length and weight measurements, sample sizes $(n)$, regression parameters $a$ and $b$ of the LWR, 95\% confidence intervals of $b$, and coefficients of determination $\left(R^{2}\right)$ of the M. mustelus are given in Table 2 . The calculated $b$ value of the LWR indicated isometric growth $(b=3)$ and the

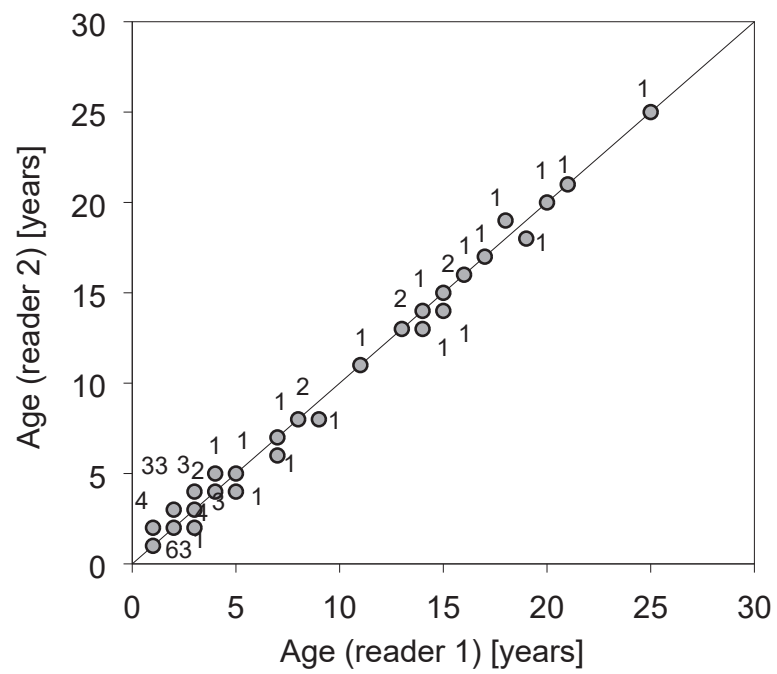

Fig. 6. Age bias plot between readers for all age estimates for Mustelus mustelus from the Gulf of Iskenderun, north-eastern Mediterranean Sea; the numbers show repeated annuli counts

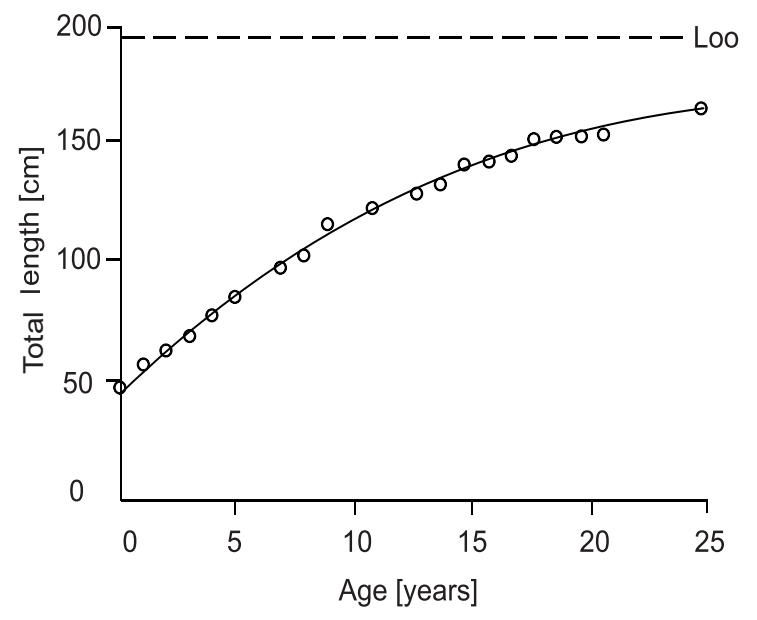

Fig. 7. Relation between the age and the total length of Mustelus mustelus from the Gulf of Iskenderun, north-eastern Mediterranean Sea 
Table 1

Length and weight of individual age groups of Mustelus mustelus from the Gulf of Iskenderun, north-eastern Mediterranean

\begin{tabular}{|c|c|c|c|c|c|}
\hline \multirow{2}{*}{ Age group } & \multirow{2}{*}{$n$} & \multicolumn{2}{|c|}{ Total length $[\mathrm{cm}]$} & \multicolumn{2}{|c|}{ Total weight $[\mathrm{g}]$} \\
\hline & & Mean & Range & Mean & Range \\
\hline 0 & 4 & 46.05 & $44.3-47.6$ & 306.61 & $241.3-422.0$ \\
\hline 1 & 43 & 55.25 & $48.8-58.2$ & 477.62 & $278.0-602.0$ \\
\hline 2 & 75 & 61.44 & $57.3-65.9$ & 663.11 & $324.0-860.0$ \\
\hline 3 & 6 & 67.08 & $66.1-69.5$ & 851.33 & $600.0-1006.0$ \\
\hline 4 & 5 & 75.02 & $73.7-77.8$ & 1130.6 & $960.0-1295.0$ \\
\hline 5 & 2 & 83.00 & $82.1-83.9$ & 1501.0 & $1486.0-1516.0$ \\
\hline 7 & 2 & 95.00 & $94.6-95.4$ & 2241.0 & $2126.0-2356.0$ \\
\hline 8 & 2 & 100.5 & $96.0-105.0$ & 3229.0 & $2666.0-3792.0$ \\
\hline 9 & 1 & 113.4 & - & 4516.0 & - \\
\hline 11 & 1 & 119.6 & - & 6000.0 & - \\
\hline 13 & 2 & 124.5 & $124.3-124.7$ & 5483.5 & $5204.0-5763.0$ \\
\hline 14 & 2 & 129.7 & $129.6-129.9$ & 6303.0 & $5794.0-6812.0$ \\
\hline 15 & 3 & 137.8 & $136.4-138.6$ & 7025.6 & $6018.0-8314.0$ \\
\hline 16 & 1 & 139.1 & - & 6775.0 & - \\
\hline 17 & 1 & 140.0 & - & 7245.0 & - \\
\hline 18 & 1 & 147.4 & - & 9108.0 & - \\
\hline 19 & 1 & 147.7 & - & 9621.0 & - \\
\hline 20 & 1 & 149.0 & - & 9776.0 & - \\
\hline 21 & 1 & 150.2 & - & 11408 & - \\
\hline 25 & 1 & 162.6 & - & 12060.0 & - \\
\hline
\end{tabular}

$n=$ number of individuals studied.

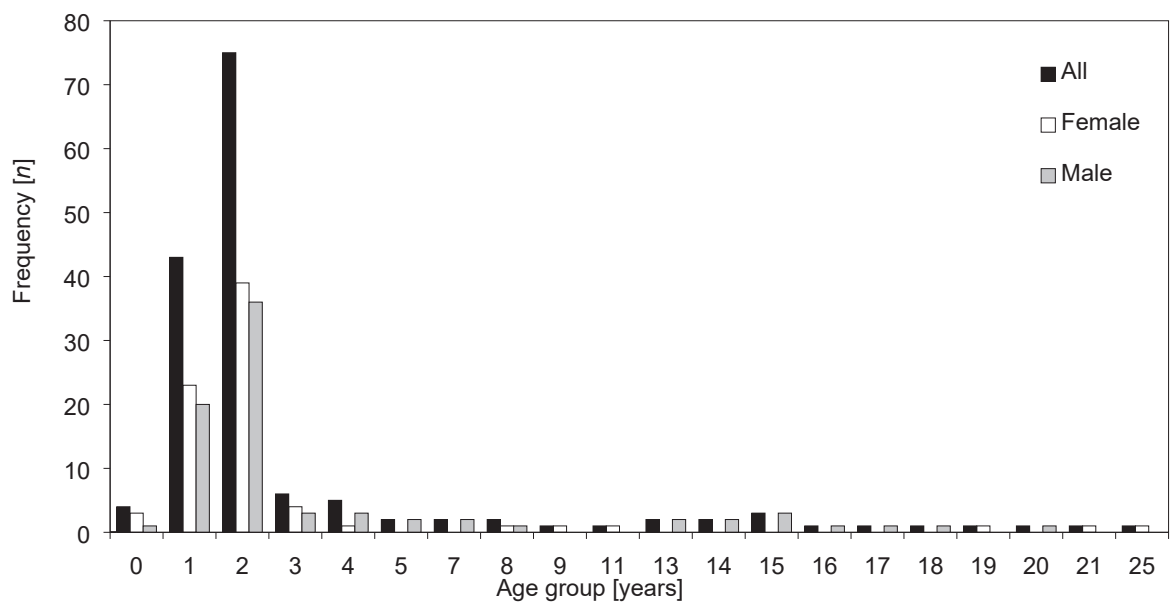

Fig. 8. Age-frequency distribution of Mustelus mustelus from the Gulf of Iskenderun, north-eastern Mediterranean Sea

Table 2

Length-weight relations for Mustelus mustelus from the Gulf of Iskenderun, north-eastern Mediterranean

\begin{tabular}{lrcccccc}
\hline \multicolumn{1}{c}{ Sex } & $n$ & Total length $[\mathrm{cm}]$ & Total weight $[\mathrm{g}]$ & $a$ & $b$ & $95 \%$ CI of $b$ & $R^{2}$ \\
\hline Female & 76 & $44.3-162.6$ & $241.3-12060.0$ & 0.0020 & 3.087 & $2.95-3.21$ & 0.97 \\
Male & 79 & $47.1-149.0$ & $315.6-8776.0$ & 0.0030 & 2.977 & $2.90-3.05$ & 0.98 \\
All & 155 & $44.3-162.6$ & $241.3-12060.0$ & 0.0027 & 3.005 & $2.93-3.07$ & 0.98 \\
\hline
\end{tabular}

$n=$ number of individuals studied, $a=$ intercept, $b=$ slope, $\mathrm{CI}=$ confidence limit, $R^{2}=$ coefficient of determination. 
coefficient of determination $\left(R^{2}\right)$ was 0.98 for $M$. mustelus (Fig. 9). Regression analysis showed that fish length has high significant correlation with weight $\left(R=0.99, R^{2}=0.98\right.$, $\left.F_{1,138}=7372.259, P<0.001\right)$ and it is possible to say that $98 \%$ increase in weight was due to length increase. Normality test was done by using the Kolmogorov-Smirnov twosample test. When the $t$-test results were analysed for the significance of regression coefficients $(t$-test $=204.916, P<$ 0.01 ), it was found that fish-length data could be used with high accuracy to predict fish weight.

Condition factor was calculated for all age groups. The highest condition factor was found at the age of $11(0.3507)$, while the lowest was found at the age of $16(0.2517)$.

Length at $50 \%$ maturity was found as $109 \mathrm{~cm}$ in females and $92 \mathrm{~cm}$ in males for M. mustelus in the northeastern Mediterranean Sea (Fig. 10). Based on length data,

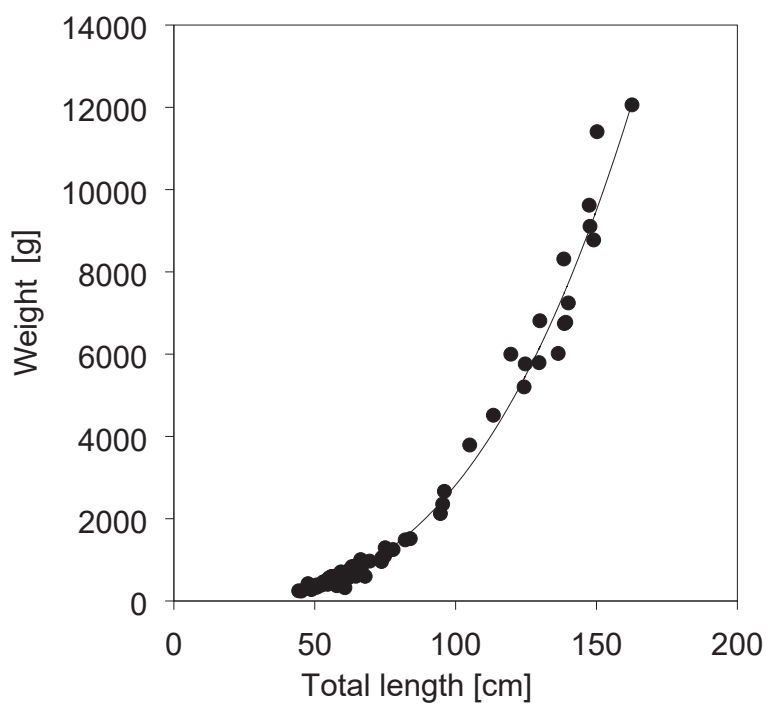

Fig. 9. Length-weight relations of Mustelus mustelus (based on all individuals) from the Gulf of Iskenderun, north-eastern Mediterranean Sea

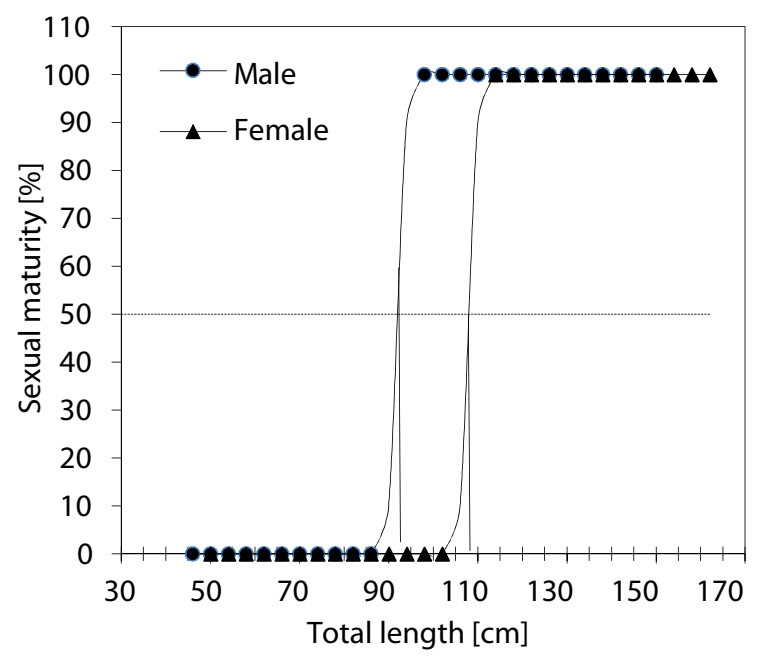

Fig. 10. Sexual maturity length of Mustelus mustelus from the Gulf of Iskenderun, north-eastern Mediterranean Sea the sexual maturity age was found to be 8 years for females and 7 years for males. As a result, it was determined that M. mustelus has reached the ability to reproduce at 7-8 years of age in the north-eastern Mediterranean Sea.

Gonadosomatic index (GSI) values varied from 0.1485 to 2.878 for females, and from 0.1038 to 0.2385 for males. It was observed that mean GSI values were low in September and July, reaching a maximum from January through February (Fig. 11).

In this study, two pregnant females of M. mustelus captured in January and in February were examined. In the first pregnant female captured in January, totally 15 embryos (10 females and 5 males) were found. Eight of them were in the right uteri and other seven were in the left uteri. The total lengths of these embryos ranged from 23.8 to $29.3 \mathrm{~cm}$ (Fig. 12a). On the other hand, in the second pregnant female caught in February, totally 10 embryos (5 females and 5 males) were observed. Five of them were in the right uteri and other five were in the left uteri. The total lengths of these embryos ranged from 23.2 to $35.6 \mathrm{~cm}$ (Fig. 12b).

\section{DISCUSSION}

In the presently reported study, the lengths and weights of Mustelus mustelus ranged from 47.1 to $149.0 \mathrm{~cm}$ and from 315.6 to $8776.0 \mathrm{~g}$ for males and from 44.3 to 162.6 $\mathrm{cm}$ and from 241.3 to $12060 \mathrm{~g}$ for females, respectively. The maximum lengths of the same species were reported as $165 \mathrm{~cm}$ for female off South Africa (Smale and Compagno 1997); $164 \mathrm{~cm}$ in Mossel Bay, South Africa (Goosen and Smale 1997); $165 \mathrm{~cm}$ in the Adriatic Sea, Mediterranean (Maddalena et al. 2001); $148.3 \mathrm{~cm}$ in the Adriatic (Pallaoro et al. 2005); $123 \mathrm{~cm}$ in the Gulf of Gabès (Saïdi et al. 2008); $122 \mathrm{~cm}$ in the Gulf of Gabès again (Saïdi et al. 2009). The maximum lengths reported around the Turkish coasts are given Table 3. In this study, the maximum lengths of females and males were found to be 162.6 to $149.0 \mathrm{~cm}$, respectively, in the north-eastern Mediterranean. These values are the highest reported for the Turkish coasts.

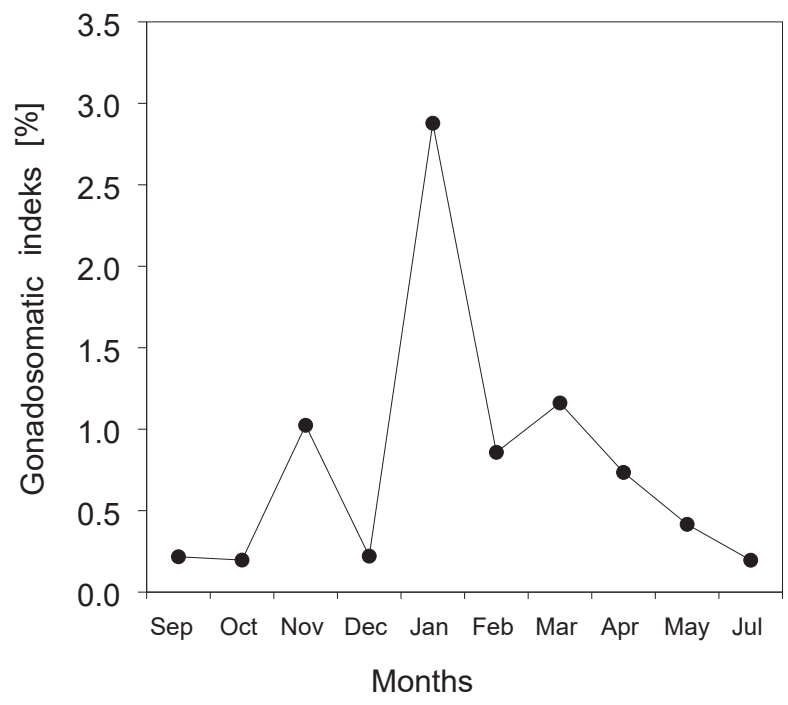

Fig. 11. Monthly fluctuations of gonadosomatic index of Mustelus mustelus from the Gulf of Iskenderun, northeastern Mediterranean Sea 
The vertebral band age readings showed that the female age ranged from 0 to $25 ; 51.51 \%$ of them were in the age group 2; while males were in the range of 0 to 20 years of age; $43.24 \%$ of them were in the age group 2. Goosen and Smale (1997) found that the age range of their females was between 0 and 24 years of age and males were between 1 and 17 years of age. Since there has been no other age study concerning this species, a comparison was made with another species of this family. For instance, a maximum age of 16 years was reported for Mustelus antarcticus Günther, 1870 (see Moulton et al. 1992); 13 for Mustelus henlei (Gill, 1863) (see Yudin and Calliet 1990); 12 for Mustelus lenticulatus Phillipps, 1932 (see Francis and Francis 1992); 9 for Mustelus californicus Gill, 1864 (see Yudin and Cailliet 1990), 9 for Mustelus manazo Bleeker, 1855 (see Tanaka and Mizue 1979); 16 for Mustelus canis (Mitchill, 1815) (see Conrath et al. 2002); 13 for Mustelus asterias Cloquet, 1819 (see Farrell et al. 2010); 16 for Mustelus walkeri White et Last, 2008 (see Rigby et al. 2016); and 11 years for Mustelus schmitti Springer, 1939 (see Molina et al. 2017).

The overall length and weight growth parameters, estimated based on the von Bertalanffy equation, assumed the following values: $L_{\infty}=195.13 \mathrm{~cm}, W_{\infty}=20060 \mathrm{~g}$, $K=0.06, t_{0}=-4.27$ years. Since there were not enough samples in the study, the above-mentioned calculations were not done separately for both sexes (females and males). All these parameters calculated for different species of the same family are summarized in Table 4.

Length-weight relations may show temporal or spatial variations due to their size range, reproductive activities, and stage or environmental factors such as water temperature, food quality and availability, diseases, and competition (Wootton 1990).

Table 3

Comparison of total length-weight relations of Mustelus mustelus in various regions

\begin{tabular}{lrrrrrl}
\hline \multicolumn{1}{c}{ Region } & $n$ & $L_{\max }$ & $a$ & $b$ & $R^{2}$ & \multicolumn{1}{c}{ Reference } \\
\hline Eastern Adriatic & 16 & 75.0 & 0.0010 & 2.758 & 0.94 & Dulčić and Kraljević 1996 \\
Northern Aegean Sea & 48 & 97.5 & 0.0008 & 3.32 & 0.97 & Filiz and Mater 2002 \\
Northern Aegean Sea & 35 & 97.5 & 0.0011 & 3.25 & 0.94 & Filiz and Bilge 2004 \\
Gulf of Izmir, Aegean Sea & 17 & 95.5 & 0.0044 & 2.91 & 0.98 & Özaydın et al. 2007 \\
North Atlantic & 46 & 132.0 & 0.0017 & 3.174 & 0.98 & Pereira et al. 2012 \\
Aegean Sea & 148 & 125.1 & 0.0030 & 3.05 & 0.97 & İlkyaz et al. 2008 \\
Gulf of Izmir, Aegean Sea & 139 & 141.1 & 0.1060 & 2.27 & 0.98 & Hepkafadar unpublished \\
Gulf of Saros, Aegean Sea & 70 & 152.2 & 0.0034 & 2.97 & 0.98 & Ismen et al. 2009 \\
Gulf of Antalya, Mediterranean & 4 & 87.4 & 0.0974 & 2.77 & 0.99 & Güven et al. 2012 \\
North-eastern Atlantic & 37 & 113.5 & 0.0330 & 3.02 & 0.99 & Wilhelms 2013 \\
Siğacık Bay, Aegean Sea & 41 & 113.3 & 0.0010 & 3.27 & 0.971 & Eronat and Özaydın 2014 \\
Southern Aegean Sea & 74 & 101.7 & 0.0053 & 2.84 & 0.98 & Bilge et al. 2014 \\
North-eastern Mediterranean & 76 & 162.6 & 0.0020 & 3.08 & 0.97 & This study \\
& 79 & 146.0 & 0.0030 & 2.97 & 0.98 & \\
\hline
\end{tabular}

Hepkafadar unpublished $=$ see footnote on page 34 .

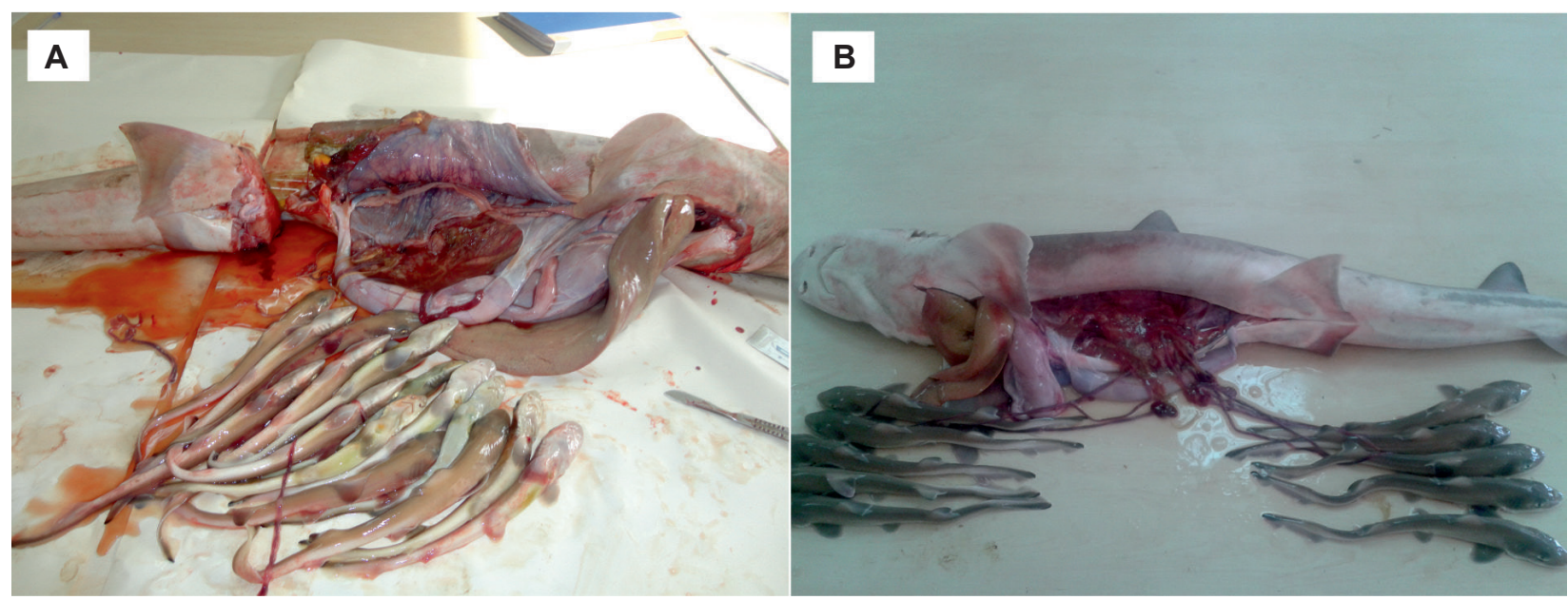

Fig. 12. Examples of dissected pregnant females of Mustelus mustelus caught in January 2014 (A) and February 2014

(B) from the Gulf of Iskenderun, north-eastern Mediterranean Sea 
Table 4

Comparison of asymptotic length $(L \infty)$, and growth coefficient $(k)$ of the von Bertalanffy growth function for 9 species of the genus Mustelus from this study and other studies

\begin{tabular}{llccl}
\hline \multicolumn{1}{c}{ Species } & \multicolumn{1}{c}{ Region } & $L_{\infty}$ & $k$ & \multicolumn{1}{c}{ Reference } \\
\hline M. schmitti & Rio Grande do Sul, Brazil & 102.8 & 0.08 & Batista unpublished \\
M. manazo & Southern Japan & 200.0 & 0.10 & Cailliet et al. 1990 \\
M. henlei & California & 97.70 & 0.24 & Yudin and Cailliet 1990 \\
M. antarcticus & Southern Australia & 200.0 & 0.10 & Moulton et al. 1992 \\
M. lenticulatus & New Zealand & 147.2 & 0.12 & Francis and Maolagáin 2000 \\
M. canis & North-western Atlantic & 120.0 & 0.29 & Conrath et al. 2002 \\
M. asterias & North-eastern Atlantic & 104.0 & 0.22 & Farrell et al. 2010 \\
M. walkeri & Australia & 200.0 & 0.07 & Rigby et al. 2016 \\
M. schmitti & Anegada Bay, Argentina & 89.40 & 0.06 & Molina et al. 2017 \\
M. mustelus & Mossel Bay, South Africa & 200.0 & 0.07 & Goosen and Smale 1997 \\
M. mustelus & North-eastern Mediterranean & 195.1 & 0.06 & This study \\
\hline
\end{tabular}

Batista unpublished = Batista V.S. 1988. Determinação de idade e análise do crescimento do cação Mustelus schmitti Springer 1939 (Elasmobranchii, Triakidae) da plataforma continental do Rio Grande do Sul. [Age determination and growth analysis of Mustelus schmitti Springer 1939 (Elasmobranchii, Triakidae) from the continental shelf of Rio Grande do Sul.] Universidade Federal do Rio Grande, Brazil. [In Portuguese.]

The lowest $b$ value was reported to be 2.77 by Hepkafadar (unpublished*) in the Gulf of Izmir, while the highest was given by Filiz and Mater (2002) in the northern Aegean Sea. The comparison of the total length-weight relations of Mustelus mustelus (Table 3) shows the differences between the patterns of growth between regions. The differences can be attributed to the combination of several factors such as the number and size of examined individuals.

Lengths at $50 \%$ maturity $\left(L_{50}\right)$ were found as $109 \mathrm{~cm}$ at 8 years of age for females and $92 \mathrm{~cm}$ at 7 years of age for males. The length at sexual maturity was reported as $125-130 \mathrm{~cm}$ for females and $95-130 \mathrm{~cm}$ for males in South Africa (Smale and Compagno 1997); 59-93 cm for females and $52-57 \mathrm{~cm}$ for males in Mauritania (Khallahi unpublished $^{* *}$ ); 90-104 cm for females and 82-95 cm for males in Senegal (Capapé et al. 2006); 107.5-123.0 cm for females and $88.0-112 \mathrm{~cm}$ for males in the Gulf of Gabès (Saïdi et al. 2008). Saïdi et al. (2008) reported that although both gonads were active in males, only right ovaries were active in females. When GSI and condition factor are evaluated together, the reproduction period of M. mustelus is estimated to take place from January to February in the north-eastern Mediterranean Sea.

These reproduction data should be taken into account for reproduction and nursery areas of M.mustelus in the north-eastern Mediterranean and decision makers dealing with fisheries management should consider establishment of marine protected areas with regional fisheries organizations. The results of this study could give useful insight for management plan and conservation of M. mustelus in the Mediterranean coast of Turkey.

\section{ACKNOWLEDGEMENTS}

The authors thank Nevruz Gayır and Yusuf Tuğcu for help in collecting the fish specimens. Fishing permit was granted by the General Directorate of Fisheries and Aquaculture, Ministry of Food, Agriculture and Livestock of the Turkish Republic. This study was supported by Firat University Scientific Research Projects Coordination (FUBAP), Project No. SUF 12.02.

\section{REFERENCES}

Bagenal T.B. 1978. Aspects of fish fecundity. Pp 75-101. In: Gerking S.D. (ed.) Ecology of freshwater fish production. Blackwell Scientific, Oxford, UK.

Bagenal T.B., Tesch F.W. 1978. Age and growth. Pp. 101136. In: Bagenal T.B. (ed.) Methods for assessment of fish production in fresh waters. 3rd edn. Blackwell Scientific Publications, Oxford, UK.

Başusta N., Demirhan S.A., Çiçek E., Başusta A., Kuleli T. 2008. Age and growth of the common guitarfish, Rhinobatos rhinobatos, in Iskenderun Bay (northeastern Mediterranean, Turkey). Journal of Marine Biological Association of the United Kingdom 88 (4): 837-842. DOI: $10.1017 / \mathrm{S} 0025315408001124$

Başusta N., Erdem U. 2000. İskenderun körfezi balıkları üzerine bir araştırma. [A study on the pelagic and demersal fishes of İskenderun Bay.] Turkish Journal of Zoology 24 (Suppl.): 1-19. [In Turkish.]

Başusta N., Sulikowski J.A. 2012. The oldest estimated age for roughtail stingray [Dasyatis centroura (Mitchill, 1815)] from the Mediterranean Sea. Journal of Applied Ichthyology 28 (4): 641-642. DOI: 10.1111/j.14390426.2012.01940.x

Beamish R.J., Fournier D.A. 1981. A method for comparing the precision of a set of age determinations. Canadian Journal of Fisheries and Aquatic Sciences 38 (8): 982-983. DOI: 10.1139/f81-132

Bilge G., Yapici S., Filiz H., Cerim H. 2014. Weightlength relations for 103 fish species from the southern Aegean Sea, Turkey. Acta Ichthyologica et Piscatoria 44 (3): 263-269. DOI: 10.3750/AIP2014.44.3.11

Cailliet G.M., Goldman K.J. 2004. Age determination and validation in chondrichthyan fishes. Pp. 399-447.

\footnotetext{
*Hepkafadar O. 2008. İzmir Körfezi’nde adi köpekbalığı (Mustelus mustelus L., 1758) avcıllı̆ı ve bazı biyolojik özellikleri üzerine araştırmalar. [Research on fishery and some biological aspects of smooth-hound shark (Mustelus mustelus L., 1758) in Izmir Bay.] MSc Thesis. Department of Fisheries and Processing Technology, Ege University, Turkey. [In Turkish.]

** Khallahi B. 2004. Ecologie et biologie de lemissole lisse M. mustelus (Linné, 1758) sur les côtes de Mauritanie. PhD Thesis. Universite' de Bretagne Occidentale, France.
} 
In: Carrier J., Musick J.A., Heithaus M.R. (eds.) Biology of sharks and their relatives. CRC Press, Boca Raton, FL, USA.

Cailliet G.M., Holts D.B., Bedford D. 1993. A review of the commercial fisheries for sharks on the west coast of United States. Pp. 13-29. In: Pepperell J., West J., Woon P. (eds.) Shark conservation: Proceedings of an International Workshop on the Conservation of Elasmobranchs, 24 February 1991, Taronga Zoo, Sydney. Conservation Research Centre, Sydney, NSW, Australia.

Cailliet G.M., Smith W.D., Mollet H.F., Goldman K.J. 2006. Age and growth studies of chondrichthyan fishes: The need for consistency in terminology, verification, validation, and growth function fitting. Environmental Biology of Fishes 77 (3-4): 211-228. DOI: $10.1007 / \mathrm{s} 10641-006-9105-5$

Cailliet G.M., Yudin K.G., Tanaka S., Taniuchi T. 1990. Growth characteristics of two populations of Mustelus manazo from Japan based upon crossreadings of vertebral bands. Pp. 167-176. In: Pratt H.L.jr., Gruber S.H., Taniuchi T. (eds.) Elasmobranchs as living resources: Advances in the biology, ecology, systematics, and the status of the fisheries. NOAA Technical Report NMFS 90.

Campana S.E. 2001. Accuracy, precision and quality control in age determination, including a review of the use and abuse of age validation methods. Journal of Fish Biology 59 (2): 197-242. DOI: 10.1111/j.10958649.2001.tb00127.x

Capapé C., Diatta Y., Diop M., Vergne Y., Guélorget O. 2006. Reproductive biology of the smoothhound, Mustelus mustelus (Chondrichthyes: Triakidae) from the coast of Senegal (eastern tropical Atlantic). Cybium 30 (3): 273-282.

Conrath C.L., Gelsleichter J., Musick J.A. 2002. Age and growth of the smooth dogfish (Mustelus canis) in the northwest Atlantic Ocean. Fishery Bulletin 100 (4): 674-682.

Conrath C.L., Musick J.A. 2002. Reproductive biology of the smooth dogfish, Mustelus canis, in the northwest Atlantic Ocean. Environmental Biology of Fishes 64 (4): 367-377. DOI: 10.1023/A:1016117415855

Dulčić J., Kraljević M. 1996. Weight-length relationships for 40 fish species in the eastern Adriatic (Croation waters). Fisheries Research 28 (3): 243-251. DOI: 10.1016/0165-7836(96)00513-9

Duman O.V., Başusta N. 2013. Age and growth characteristics of marbled electric ray Torpedo marmorata (Risso, 1810) inhabiting Iskenderun Bay, north-eastern Mediterranean Sea. Turkish Journal of Fisheries and Aquatic Sciences 13 (3): 551-559.

Eronat E.G.T., Özaydın O. 2014. Length-weight relationship of cartilaginous fish species from central Aegean Sea (Izmir Bay and Siğacık Bay). Ege Journal of Fisheries and Aquatic Sciences 31 (3): 119-125. DOI: 10.12714/egejfas.2014.31.3.01

Farrell E.D., Mariani S., Clarke M.W. 2010. Age and growth estimates for the starry smoothhound
(Mustelus asterias) in the Northeast Atlantic Ocean. ICES Journal of Marine Science 67 (5): 931-939. DOI: $10.1093 /$ icesjms/fsp295

Filiz H., Bilge G. 2004. Length-weight relationships of 24 fish species from the north Aegean Sea, Turkey. Journal of Applied Ichthyology 20 (5): 431-432. DOI: $10.1111 /$ j.1439-0426.2004.00582.x

Filiz H., Mater S. 2002. A preliminary study on lengthweight relationships for seven elasmobranch species from north Aegean Sea, Turkey. Ege Journal of Fisheries and Aquatic Sciences 19 (3-4): 401-409.

Francis M.P., Francis R.I.C.C. 1992. Growth rate estimates for New Zealand rig (Mustelus lemiculatus). Australian Journal of Marine and Freshwater Research 43 (5): 1157-1176. DOI: 10.1071/MF9921157

Francis M.P., Maolagáin C. 2000. Age, growth and maturity of a New Zealand endemic shark (Mustelus lenticulatus) estimated from vertebral bands. Marine and Freshwater Research 51 (1): 35-42. DOI: 10.1071/ MF99012

Ghorbel M., Jarboui O., Bradaï M.N., Bouaïn A. 1996. Détermination de la taille de première maturité sexuelle par une fonction logistique chez Limanda limanda, Pagellus erythrinus et Scorpaena porcus. Bulletin de l'Institut National des Sciences et Technologies de la Mer 3: 24-27.

Girgin H., Başusta N. 2016. Testing staining techniques to determine age and growth of Dasyatis pastinaca (Linnaeus, 1758) captured in Iskenderun Bay, northeastern Mediterranean. Journal of Applied Ichthyology 32 (3): 595-601. DOI: 10.1111/jai.13077

Golani D., Öztürk B., Başusta N. 2006. Fishes of the eastern Mediterranean. Turkish Marine Research Foundation, Istambul, Turkey.

Goosen A.J., Smale M.J. 1997. A preliminary study of age and growth of the smooth-hound shark Mustelus mustelus (Triakidae). South African Journal of Marine Science 18 (1): 85-91. DOI: $10.2989 / 025776197784161072$

Güven O., Kebapçioğlu T., Deval M.C. 2012. Lengthweight relationships of sharks in Antalya Bay, eastern Mediterranean. Journal of Applied Ichthyology 28 (2): 278-279. DOI: 10.1111/j.1439-0426.2011.01823.x

Hossain M.Y., Rahman M.M., Abdallah E.M., Ohtomi J. 2013. Biometric relationships of the pool barb Puntius sophore (Hamilton 1822) (Cyprinidae) from three major rivers of Bangladesh. Sains Malaysiana 42 (11): 1571-1580.

İlkyaz A.T., Metin G., Soykan O., Kinacigil H.T. 2008. Length-weight relationship of 62 fish species from the central Aegean Sea, Turkey. Journal of Applied Ichthyology 24 (6): 699-702. DOI: 10.1111/j.14390426.2008.01167.x

Ismen A., Yigin C.C., Altinagaç U., Ayaz A. 2009. Length-weight relationships for ten shark species from Saros Bay (north Aegean Sea). Journal of Applied Ichthyology 25 (Suppl. 1): 109-112. DOI: $10.1111 /$ j.1439-0426.2009.01263.x 
King M. 1995. Fisheries biology, assessment and management. Fishing News Books, Blackwell Science, Oxford, UK.

Maddalena A., Piscitelli L., Malandra R. 2001. The largest specimen of smooth-hound, Mustelus mustelus (Linnaeus, 1758), recorded from the Mediterranean Sea. Bilješke - Notes 2001 (84): 1-8.

Martin L.K., Cailliet G.M. 1988. Age and growth determination of the bat ray, Myliobatis californica Gill, in central California. Copeia 1988 (3): 762-773. DOI: $10.2307 / 1445399$

Molina J.M., Blasina G.E., Lopez Cazorla A.C. 2017. Age and growth of the highly exploited narrownose smooth-hound (Mustelus schmitti) (Pisces: Elasmobranchii). Fishery Bulletin 115 (3): 365-379. DOI: $10.7755 / \mathrm{FB} \cdot 115.3 .7$

Moulton P.L., Walker T., Saddlier S.R. 1992. Age and growth of gummy shark, Mustelus antarcticus Gunther, and school shark, Galeorhinus galeus (Linnaeus), from southern Australian Waters. Australian Journal of Marine and Freshwater Research 43 (5): 1241-1267. DOI: 10.1071/MF9921241

Natanson L.J., Casey J.G., Kohler N. 1995. Age and growth estimates for the dusky shark, Carcharhinus obscurus, in the western North Atlantic Ocean. Fishery Bulletin 93: 116-126.

Özaydın O., Uçkun D., Akalın S., Leblebici S., Tosunoğlu Z. 2007. Length-weight relationships of fishes captured from Izmir Bay, central Aegean Sea. Journal of Applied Ichthyology 23 (6): 695-696. DOI: $10.1111 /$ j.1439-0426.2007.00853.x

Özcan E.İ., Başusta N. 2016. Kuzeydoğu Akdeniz bölgesinde yaşayan adi köpekbalığı, Mustelus mustelus (Linnaeus, 1758)'un mide içeriği. [Digestive system contents of Mustelus mustelus (Linnaeus, 1758) inhabiting northeastern Mediterranean.] Firat Üniversitesi Fen Bilimleri Dergisi - Firat University Journal of Science 28 (1): 7-12. [In Turkish.]

Pallaoro A., Jardas I., Šantić M. 2005. Weight-length relationships for 11 chondrichthyan species in the eastern Adriatic Sea. Cybium 29 (1): 93-96.

Pereira J. N., Simas A., Rosa A., Aranha A., Lino S., Constantino E., Monteiro V., Tariche O., Menezes G. 2012. Weight-length relationships for 27 demersal fish species caught off the Cape Verde archipelago (eastern North Atlantic). Journal of Applied Ichthyology 28 (1): 156-159. DOI: 10.1111/j.14390426.2011.01915.x

Rigby C.L., White W.T., Smart J.J., Simpfendorfer C.A. 2016. Life histories of two deep-water Australian endemic elasmobranchs: Argus skate Dipturus polyommata and eastern spotted gummy shark Mustelus walkeri. Journal of Fish Biology 88 (3): 1149-1174. DOI: 10.1111/jfb.12891

Saïdi B., Bradaï M.N., Bouaïn A. 2008. Reproductive biology of the smooth-hound shark Mustelus mustelus (L.) in the Gulf of Gabès (south-central Mediterranean Sea). Journal of Fish Biology 72 (6): 1343-1354. DOI: 10.1111/j.1095-8649.2008.01801.x

Saïdi B., Enajjar S., Bradaï M.N., Bouaïn A. 2009. Diet composition of smooth-hound shark, Mustelus mustelus (Linnaeus, 1758), in the Gulf of Gabès, southern Tunisia. Journal of Applied Ichthyology 25 (Suppl. 1): 113-118. DOI: 10.1111/j.14390426.2009.01306.x

Serena F., Mancusi C., Clò S., Ellis J., Valenti S.V. 2009. Mustelus mustelus. The IUCN Red List of Threatened Species 2009: e.T39358A10214694. DOI: 10.2305/ IUCN.UK.2009-2.RLTS.T39358A10214694.en

Smale M.J., Compagno L.J.V. 1997. Life history and diet of two southern African smoothhound sharks, Mustelus mustelus (Linneaus, 1758) and Mustelus palumbes Smith, 1957 (Pisces: Triakidae). South African Journal of Marine Science 18 (1): 229-248. DOI: $10.2989 / 025776197784160992$

Sulikowski J.A., Kneebone J., Elzey S., Jurek J., Danley P.D., Howell W.H., Tsang P.C.W. 2005. Age and growth estimates of the thorny skate (Amblyraja radiata) in the western Gulf of Maine. Fishery Bulletin 103 (1): 161-168.

Sulikowski J.A., Morin M.D., Suk S.H., Howell W.H. 2003. Age and growth estimates of the winter skate (Leucoraja ocellata) in the western gulf of Maine. Fishery Bulletin 101 (2): 405-413.

Tanaka S., Mizue K. 1979. Studies on sharks-XV. Age and growth of Japanese dogfish Mustelus manazo Bleeker in the East China Sea. Bulletin of the Japanese Society of Scientific Fisheries 45(1): 43-50. DOI: $10.2331 /$ suisan.45.43

Türkmen M., Başusta N., Demirhan S.A. 2005. Balıklarda yaş tayini. [Age determination in fish.] Pp: 121-148. In: Karatas M. (ed.) Balık biyolojisi araştırma yöntemleri. [Research techniques in fish biology.] Nobel Akademik Yayıncılık, Ankara, Turkey. [In Turkish.]

von Bertalanffy L. 1938. A quantitative theory of organic growth (inquiries of growth laws II). Human Biology 10 (2): 181-213.

Wilhelms I. 2013. Atlas of length-weight relationships of 93 fish and crustacean species from the North Sea and the North-East Atlantic. Thünen Working Paper No. 12. Thünen-Institut, Bundesforschungsinstitut für Ländliche Räume, Wald und Fischerei, Braunschweig, Germany. DOI: 10.3220/WP_12_2013

Wootton R.J. 1990. Ecology of teleost fishes. Chapman and Hall, Upper Saddle River, NJ, USA.

Yudin G.K., Cailliet M.G. 1990. Age and growth of the gray smoothhound, Mustelus californicus, and the brown smoothhound, M. henlei, sharks from central California. Copeia 1990 (1): 191-204. DOI: $10.2307 / 1445835$

Received: 15 August 2017

Accepted: 10 January 2018

Published electronically: 31 March 2018 